\title{
CARBON ISOTOPE DYNAMICS IN SOME TROPICAL SOILS
}

\section{PETER BECKER-HEIDMANN and H-W SCHARPENSEEL}

\author{
Institut für Bodenkunde, Universität Hamburg \\ Federal Republic of Germany
}

\begin{abstract}
We determined $\delta^{13} \mathrm{C}$ and $\mathrm{D}^{14} \mathrm{C}$ in some agricultural soil profiles of the tropics: Ustalf from the semi-arid tropics (India), a Udult, an Aquoll and an Aquept from the humid tropics (Philippines). We used a thin-layer sampling, resulting in high-resolution depth-distribution patterns of natural ${ }^{13} \mathrm{C}$ and ${ }^{14} \mathrm{C}$ content of organic carbon. Regular plowing or puddling leads to uniform isotope concentrations in the topsoil. Decomposition of organic matter raises the $\delta^{13} \mathrm{C}$ value, and vertical translocation raises the $\delta^{13} \mathrm{C}$ value with depth. The change of cultivation from pulses (C3-type metabolism of photosynthesis) to sorghum (C4) results in a decrease of $\delta^{13} \mathrm{C}$ with depth in the topsoil. Where the clay content in the subsoil is high, $\delta^{13} \mathrm{C}$ remains constant, due to fixation of organic carbon to clay minerals, and $\mathrm{D}^{14} \mathrm{C}$ decreases with depth. Below the clay-enriched zone, $\delta^{13} \mathrm{C}$ declines and $\mathrm{D}^{14} \mathrm{C}$ rises again, due to a chromatographic-like effect. At some horizon boundaries, inhomogeneities in texture delay percolation locally, thus preventing sorption and causing peak values of $\mathrm{D}^{14} \mathrm{C}$.
\end{abstract}

\section{INTRODUCTION}

The lack of detailed information on the transformation and translocation processes of organic matter in the subsoil, which are essential for a better understanding of the global carbon cycle, led to several investigations of natural carbon-isotope depth distributions in the soil ( $c f$, eg, Stout, Goh \& Rafter, 1981). We have been studying different soil orders, beginning with Alfisols of temperate forests (Becker-Heidmann \& Scharpenseel, 1986). We are continuing this work on agricultural and tropical soils, which we present here.

\section{SITES AND METHODS}

We sampled four agricultural soil profiles during the dry season of 1983 in India and the Philippines. The climatic conditions of the profiles, their $U$ S Department of Agriculture (USDA) classification and their contemporary use are listed in Table 1.

The Udic Rhodustalf from Patancheru at the site of the International Crop Research Institute for the Semiarid Tropics (ICRISAT) near Hyderabad, India, is a red loamy soil. Because it is a Benchmark soil, its properties are well known (Murthy et al, 1982). The Tiaong silty clay loam and the Los Baños clay soil are located at experimental sites of the International Rice Research Institute (IRRI), Luzon, Philippines. While the Tiaong soil is not plowed but carries banana and coconut trees, the Los Baños soil is used for wetland rice. The site in San Dionisio on the Philippine island of Panay has been under rice cultivation until the discovery of large deposits of kaolinite clay below $3 \mathrm{~m}$ depth. The characteristic data of the profiles are summarized in Table 2 .

Thin-layer sampling of complete soil monoliths cut into $2 \mathrm{~cm}$ slices and ${ }^{13} \mathrm{C}$ and ${ }^{14} \mathrm{C}$ analyses of these were described earlier (Becker-Heidmann \& Scharpenseel, 1986). 
TABLE 1

Soil profiles

\begin{tabular}{lllrrl}
\hline Profile & $\begin{array}{c}\text { Soil order (USDA } \\
\text { classification) }\end{array}$ & $\begin{array}{c}\text { Tropical } \\
\text { climate }\end{array}$ & $\begin{array}{c}\text { Temp } \\
\left({ }^{\circ} \mathrm{C}\right)\end{array}$ & $\begin{array}{c}\text { Rainfall } \\
(\mathrm{mm})\end{array}$ & Cultivation \\
\hline Patancheru & Udic Rhodustalf & Semi-arid & 25.8 & 760 & Pulses, sorghum \\
Tiaong & Typic Haplaquoll & Humid & 26.0 & 2150 & Banana, coconut \\
Los Baños & Aeric Tropaquept & Humid & 26.0 & 2150 & Wetland rice \\
San Dionisio & Typic Paleudult & Humid & 26.0 & 3000 & Wetland rice* \\
\hline
\end{tabular}

*Fallowed in recent years

TABLE 2

Profile characteristics

\begin{tabular}{lcccccc}
\hline Profile & $\begin{array}{c}\text { Depth } \\
(\mathrm{cm})\end{array}$ & $\mathrm{pH}$ & $\begin{array}{c}\text { Organic C } \\
(\%)\end{array}$ & $\begin{array}{c}\text { Clay } \\
(\%)\end{array}$ & $\begin{array}{c}\text { Silt } \\
(\%)\end{array}$ & $\begin{array}{c}\text { Sand } \\
(\%)\end{array}$ \\
\hline Patancheru & 158 & $6.7-5.7$ & $0.7-0.2$ & $19-40$ & $4-7$ & $81-56$ \\
Tiaong & 54 & $6.3-7.2$ & $4.0-0.3$ & $23-36$ & $58-47$ & $19-12$ \\
Los Baños & 80 & $6.0-6.7$ & $2.3-0.2$ & $53-62$ & $39-26$ & $5-19$ \\
San Dionisio & 80 & $3.7-4.2$ & $1.5-0.5$ & $19-47$ & $58-45$ & $17-8$ \\
\hline
\end{tabular}

\section{RESULTS AND DISCUSSION}

The ${ }^{14} \mathrm{C}$ data are reported as $\mathrm{D}^{14} \mathrm{C}$, following the recommendations of Stuiver and Polach (1977). Four zones can be distinguished in the Patancheru profile (Fig 1). $\mathrm{D}^{14} \mathrm{C}$ is equal to the atmospheric bomb carbon level only in the topmost $2 \mathrm{~cm}$ layer. $\mathrm{D}^{14} \mathrm{C}$ is nearly uniform, as expected, but $<200 \%$ below the first $4 \mathrm{~cm}$ of the plowed horizon. This indicates low annual $\mathrm{C}$ input combined with rapid turnover, in accordance with the low $\mathrm{C}$ content of the soil (see Table 2). The $\delta^{13} \mathrm{C}$ value decreases from $-15 \%$ to $-18 \%$. $\delta^{13} \mathrm{C}$ usually is not only more negative but also increases with depth in the topsoil, correlating with $\mathrm{C} 3$ plants and the increasing decomposition stage of organic matter with depth (Stout, Goh \& Rafter, 1981; O'Brien \& Stout, 1978; Becker-Heidmann \& Scharpenseel, 1986). The reason for a different curve in this profile is probably a recent change in cultivation from pulses (C3 plants) to sorghum (C4). Some of the fresh organic substances with higher $\delta^{13} \mathrm{C}$ values move downwards and are added to the older organic matter, which originated in the $\mathrm{C} 3$ crops. Below $\mathrm{Ap}$ and $\mathrm{A} 1, \delta^{13} \mathrm{C}$ shows a normal pattern. From $\mathrm{A} 12$ to $\mathrm{B} 21 \mathrm{t}$ horizons, $\mathrm{D}^{14} \mathrm{C}$ decreases continuously until it is ca $-400 \%$, corresponding to a rapidly decreasing rejuvenation by translocated carbon. Accordingly, increasing $\delta^{13} \mathrm{C}$ shows a rise in more decomposed organic matter with depth. In the B22t horizon then, the tendencies of both $\mathrm{D}^{14} \mathrm{C}$ and $\delta^{13} \mathrm{C}$ inflect coincidently with the beginning of the decline of the clay content. We also found the same effect in Alfisols from temperate zone forests (Becker-Heidmann \& Scharpenseel, 1986). This can be explained by a chromatographic-like effect: older and highly metabolized 


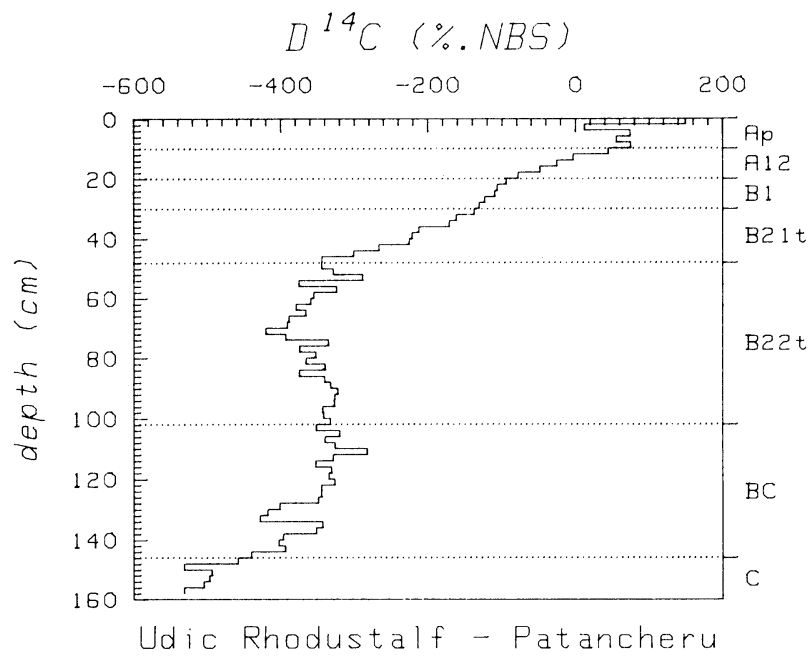

Fig $1 \mathrm{~A} . \mathrm{D}^{14} \mathrm{C}$ distribution of the Patancheru profile

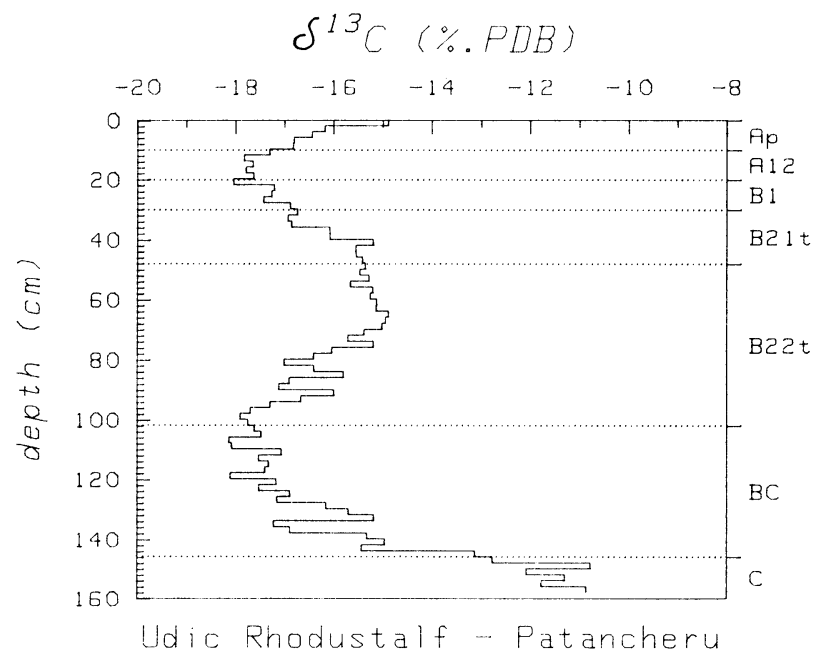

Fig $1 \mathrm{~B} . \delta^{13} \mathrm{C}$ distribution of the Patancheru profile 
organic matter is relatively well-adsorbed or complexated with clay, and is prevented from permanent rejuvenation by young percolating organic substances. Thus, the latter are transported to the lower part of the soil. Because of the low precipitation at Patancheru, little young organic matter enters and moves downwards into the profile. But with decreasing amounts of clay and, consequently, of clay-complexated old organic matter, the influence of young organic matter grows with depth. In the deepest part of the profile, the circumstances are similar to those in A12 to B21t.

The Tiaong soil is not plowed; thus, its $\mathrm{A} 11$ horizon shows a $\mathrm{D}^{14} \mathrm{C}$ maximum between 6 and $8 \mathrm{~cm}$ below surface, in the main rooty zone, with a constant decrease below (Fig 2). In the A12 and B2g horizons, there are only a few layers where $\mathrm{D}^{14} \mathrm{C}<0$. This means that a continuous admixture of fresh organic matter is occuring throughout the whole profile. Because of the wet conditions combined with non-intensive cultivation, an accumulation of organic matter is probable ( $c f$ Table 2). As in the Patancheru profile, with decreasing clay content $\delta^{13} \mathrm{C}$ decreases with depth and $\mathrm{D}^{14} \mathrm{C}$ increases slightly. At the transition zone between the A12 and the watersaturated B2g horizon, the redox potential seasonally changes with the groundwater level, which is proven by a strong enrichment of $\mathrm{Mn}$ in the layers of the $\mathrm{D}^{14} \mathrm{C}$ peaks. These conditions prevent fixation and aging of organic substances and lead to the "modern" $\mathrm{D}^{14} \mathrm{C}$ peak.

Because of intensive rice cultivation, the Los Baños profile has a lower organic $\mathrm{C}$ content and, consequently, a higher $\mathrm{D}^{14} \mathrm{C}$ level in the topsoil than the Tiaong profile (see Fig 3 ). $\mathrm{D}^{14} \mathrm{C}$ is uniform down to $8 \mathrm{~cm}$, with a value of $210 \%$; below, in the main rooty zone, there is a maximum, as in the Tiaong soil. The uniform value of $\delta^{13} \mathrm{C}$ in the entire Ap1g horizon indicates regular homogenization by puddling, whereas the Ap2g seems to be rarely puddled. The steep slope of the $\mathrm{D}^{14} \mathrm{C}$ and the $\delta^{13} \mathrm{C}$ curve at the plow pan, together with the low $\mathrm{C}$ content and maximum clay concentration at this layer, indicates a strong fixation of highly metabolized and aged humic substances to the clay. The percolating younger material passes through to the bottom, as can be concluded from both the $\delta^{13} \mathrm{C}$ inflection and the high $\mathrm{D}^{14} \mathrm{C}$ values in the whole basal soil. Spikes of high-concentration bomb carbon can be found in the lower part of the $D^{14} \mathrm{C}$ depth-distribution curve. These are located exactly at the transition layers of adjacent horizons, where there are wetter conditions than in the middle of the horizons, because drainage is impeded by texture changes. Thus, percolating organic matter cannot be bound permanently to clay in these layers, which would raise the ${ }^{14} \mathrm{C}$ age. Another explanation could be that fine roots would concentrate in these layers and, because of their high turnover rate, permanently introduce modern $\mathrm{C}$. However, the amount of fresh root material necessary for such a shift in $\mathrm{D}^{14} \mathrm{C}$ would also significantly alter $\delta^{13} \mathrm{C}$, which has not been observed.

The depth-distribution patterns of $\mathrm{D}^{14} \mathrm{C}$ and $\delta^{13} \mathrm{C}$ in the soil profile of San Dionisio are somewhat different (Fig 4). The topsoil looks wellhomogenized by regularly puddling, at least down to $12 \mathrm{~cm}$. Organic matter in the puddling zone is dominated by bomb carbon, which indicates a high turnover rate. We expected a more negative value of $\delta^{13} \mathrm{C}$ in a rice paddy. 


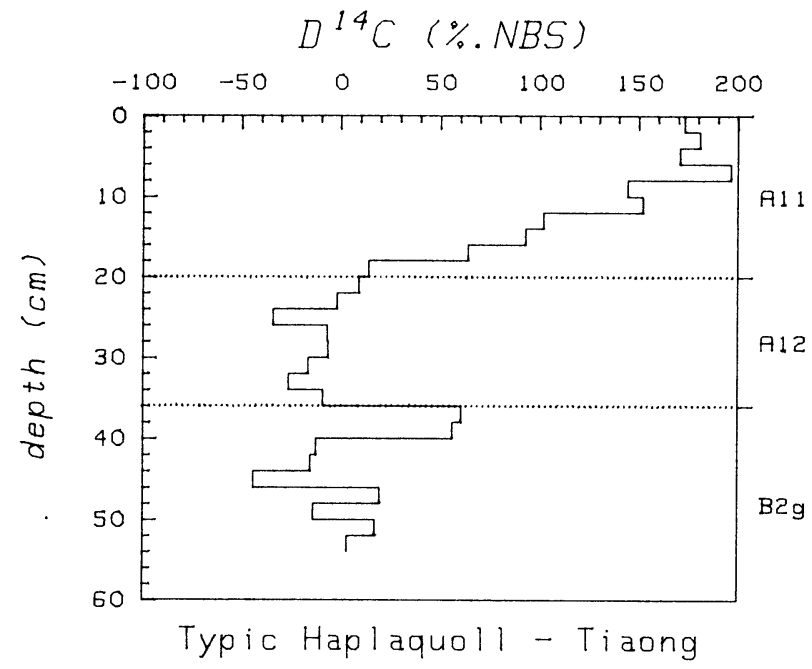

Fig $2 \mathrm{~A}$. $\mathrm{D}^{14} \mathrm{C}$ distribution of the Tiaong profile

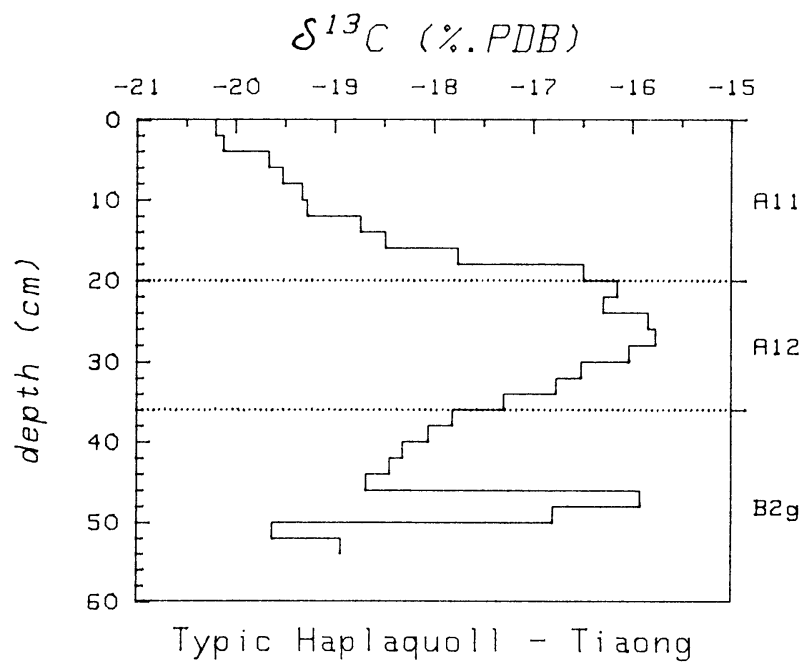

Fig $2 \mathrm{~B} . \delta^{13} \mathrm{C}$ distribution of the Tiaong profile 


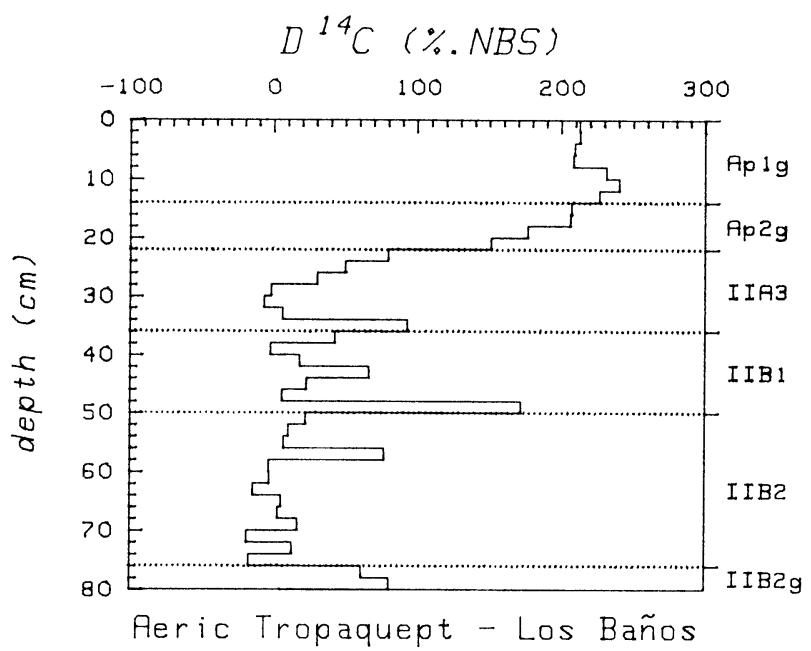

Fig $3 \mathrm{~A} . \mathrm{D}^{14} \mathrm{C}$ distribution of the Los Baños profile

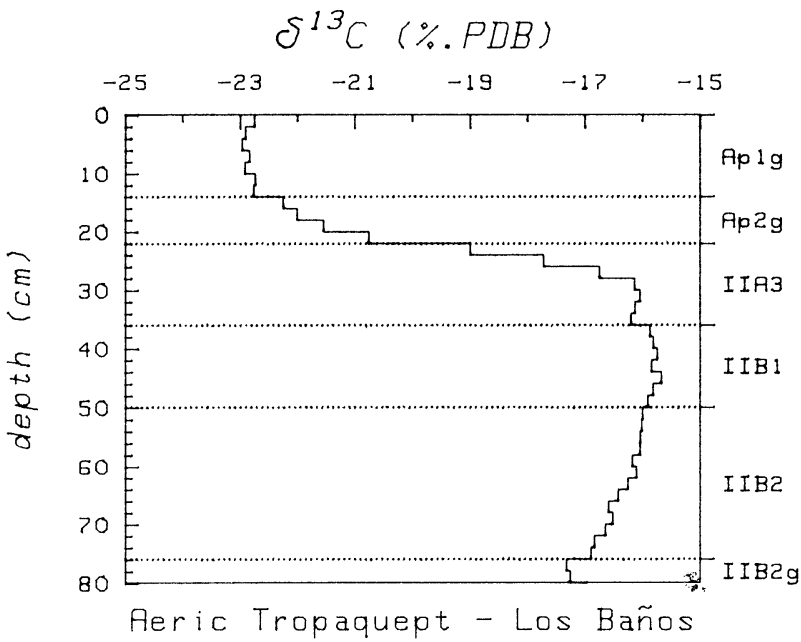

Fig 3B. $\delta^{13} \mathrm{C}$ distribution of the Los Baños profile 


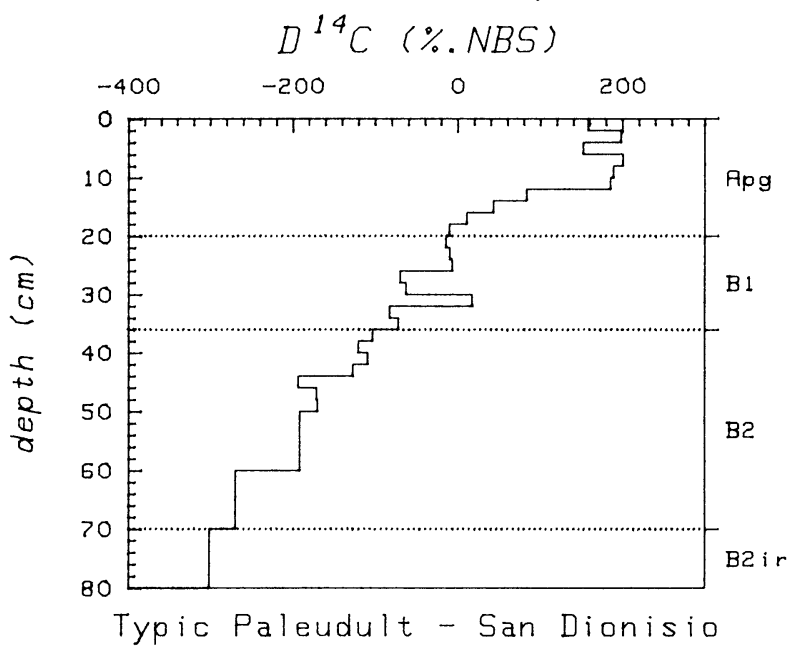

Fig 4A. $\mathrm{D}^{14} \mathrm{C}$ distribution of the San Dionisio profile

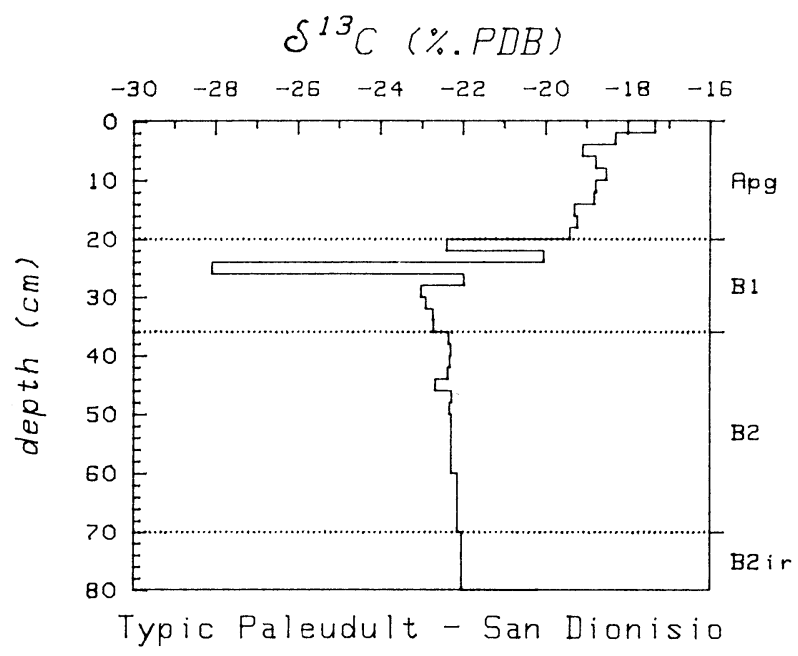

Fig 4B. $\delta^{13} \mathrm{C}$ distribution of the San Dionisio profile

However, after three years of lying fallow, the field is covered by tropical grasses, among which are probably some $\mathrm{C} 4$ species. The reason for $\delta^{13} \mathrm{C}$ fluctuations observed in the layers of the compacted plow pan, which con- 
centrates clay and silt, without a counterpart in $\mathrm{D}^{14} \mathrm{C}$, is not yet clear. The soil below that layer shows a constant $\delta^{13} \mathrm{C}$ value with a continuous and rapid decrease in $\mathrm{D}^{14} \mathrm{C}$. We conclude that organic matter in the lower part of the profile is well protected against further metabolization or admixture of young material. In fact, the soil is iron toxic, caused by low $\mathrm{pH}$ and low cation exchange capacity of the main clay mineral kaolinite. Thus, most of the organic matter gets oxidized in the topsoil and only very few metabolites percolate through the soil.

\section{CONCLUSIONS}

Definite depth distributions of $\delta^{13} \mathrm{C}$ and $\mathrm{D}^{14} \mathrm{C}$ can be correlated to different processes of soil organic-matter dynamics. Uniform isotope concentrations in the topsoil are the result of regular plowing and puddling. Recent change of vegetation or cultivation from $\mathrm{C} 3$ to $\mathrm{C} 4$ plants yield descending values of both $\delta^{13} \mathrm{C}$ and $\mathrm{D}^{14} \mathrm{C}$ with increasing depth in the topsoil. In most soils, however, an increase of $\delta^{13} \mathrm{C}$ with depth, together with a decrease of $\mathrm{D}^{14} \mathrm{C}$, indicate decomposition and metabolism of organic matter and vertical translocation of metabolites. If there is a clay-enrichment zone in the subsoil, an inflection of both isotope curves, eg, descending $\delta^{13} \mathrm{C}$ paralleled with increasing $\mathrm{D}^{14} \mathrm{C}$ below the maximum clay accumulation, can be interpreted as a chromatographic-like separation of old and young organic matter. Single $\mathrm{D}^{14} \mathrm{C}$ peaks, found at horizon boundaries, where the texture changes, are most probably the result of locally delayed percolation and, consequently, constant rejuvenation.

\section{ACKNOWLEDGMENTS}

We are indebted to $M$ Wurzer, $\mathrm{H}$ U Neue and P Singh for their assistance in selecting and sampling the soil profiles, and for providing us with additional soil data. We gratefully acknowledge the diligence and skill of our technical assistants, I Briese, A Jordan, J Ludwig and S Bielfeldt. The work was funded by the Deutsche Gesellschaft für Wirtschaftliche Zusammenarbeit $(\mathrm{GWZ})$. Financial support for the $\delta^{13} \mathrm{C}$ analyses was given by the Deutsche Forschungsgemeinschaft (DFG).

\section{REFERENCES}

Becker-Heidmann, $\mathrm{P}$ and Scharpenseel, $\mathrm{H} \mathrm{W}, 1986$, Thin layer $\delta^{13} \mathrm{C}$ and $\mathrm{D}^{14} \mathrm{C}$ monitoring of "Lessive" soil profiles, in Stuiver, $\mathrm{M}$ and $\mathrm{Kra}, \mathrm{R} \mathrm{S}$, eds, Internatl ${ }^{14} \mathrm{C}$ conf, 12 th, Proc: Radiocarbon, v 28, no. 2A, p 383-390.

Murthy, R S, Hirekerur, L R, Deshpande, S B and Venkata Rao, B V, eds, 1982, Benchmark soils of India: Bangalore, Natl Bur Soil Survey Land Use Planning.

O'Brien, B J and Stout, J D, 1978, Movement and turnover of soil organic matter as indicated by carbon isotope measurements: Soil Biol Biochem, v 10, p 309-317.

Stuiver, M and Polach, H A, 1977, Discussion: Reporting of ${ }^{14} \mathrm{C}$ data: Radiocarbon, v 19, no. 3 , p 355-363.

Stout, J D, Goh, K M and Rafter, T A, 1981, Chemistry and turnover of naturally occurring resistant organic compounds in soil, in Paul, E A and Ladd, J N, eds, Soil biochemistry: New York, Marcel Dekker, p 1-73. 